\title{
Historiography and the Law of Property Act 1925: the return of Frankenstein
}

DOI:

$10.1017 / \mathrm{S} 0008197318000697$

\section{Document Version}

Accepted author manuscript

Link to publication record in Manchester Research Explorer

\section{Citation for published version (APA):}

Roche, J. (2018). Historiography and the Law of Property Act 1925: the return of Frankenstein. The Cambridge Law Journal. https://doi.org/10.1017/S0008197318000697

\section{Published in:}

The Cambridge Law Journal

\section{Citing this paper}

Please note that where the full-text provided on Manchester Research Explorer is the Author Accepted Manuscript or Proof version this may differ from the final Published version. If citing, it is advised that you check and use the publisher's definitive version.

\section{General rights}

Copyright and moral rights for the publications made accessible in the Research Explorer are retained by the authors and/or other copyright owners and it is a condition of accessing publications that users recognise and abide by the legal requirements associated with these rights.

\section{Takedown policy}

If you believe that this document breaches copyright please refer to the University of Manchester's Takedown Procedures [http://man.ac.uk/04Y6Bo] or contact uml.scholarlycommunications@manchester.ac.uk providing relevant details, so we can investigate your claim.

\section{OPEN ACCESS}




\title{
HISTORIOGRAPHY AND THE LAW OF PROPERTY ACT 1925: \\ THE RETURN OF FRANKENSTEIN
}

\author{
JUANITA ROCHE*
}

[forthcoming in the Cambridge Law Journal, 2018]

ABSTRACT: This article considers how problems in legal historiography can lead to real legal problems, through a case-study of two recent judgments which appear to revolutionise the law on overreaching under s.2(1)(ii) Law of Property Act 1925. Their reasoning ignored plain wording in the Act, in a way foreshadowed by problems in the historiography of the 1925 property legislation; and the legislative history shows that the version of overreaching they promote, one with a clear political meaning, was rejected by Parliament. One of these decisions has now been reversed on appeal, but on reasoning so untenable as to invite further challenge; and now two Court of Appeal judgments on overreaching contradict, without even mentioning, two prior Court of Appeal decisions and a decision of the House of Lords. The court should reaffirm the law on overreaching, and academics should develop a new historiography.

KEYWORDS: legal history, legislative history, land law, overreaching, trustees, legal estates, equitable interests

\section{INTRODUCTION}

The Law of Property Act 1925 is central to English land law; beliefs about its character and purpose can have serious effects. This article discusses how problems in 
the historiography of the 1925 property legislation led to judicial wrong turns in two recent cases; how historical research can help the court undo the damage; and how a better understanding of the legislative history of the 1925 Acts and their historical context points toward a more faithful and fruitful understanding of English land law.

\section{A. A Short Historiography}

The first historical work on the development of the 1925 legislation-six Acts including the Law of Property Act 1925 ("the LPA 1925")— was by Avner Offer, in a 1977 article and a 1981 monograph. ${ }^{1}$ Offer was an economic historian, not a lawyer, nor a political historian. He assumed that property simply meant ownership, and in an extreme version, "an exclusive right to enjoy or dispose of the object without hindrance"; complexity in buying and selling land was "mystification" created by lawyers in their own economic interests. ${ }^{2}$ The debates leading to the 1925 legislation, from the mid-nineteenth century on, were a battle between "the goodies", namely

\footnotetext{
* Lecturer in Property Law, University of Manchester; Fellow, Cambridge Centre for Property Law. Address for Correspondence: School of Law, University of Manchester, Manchester M13 9PL, UK. Email: juanita.roche@manchester.ac.uk. I am grateful to the Parliamentary Archivists, for finding a lost Bill, and to Martin Dixon, Hazel Carty, Michael Haley, John Bell, and the anonymous reviewers, for their very helpful comments on earlier drafts. All faults remain my own.

${ }^{1}$ A. Offer, "The Origin of the Law of Property Acts 1910-1925" (1977) 40 M.L.R. 505 and Property and Politics 1870-1914 (Cambridge 1981), the latter covering 1826 to 1925; J. Getzler, "Publication Review: Property and Politics and Lawyers and the Making of English Land Law" (1993) 109 L.Q.R. 684; A.W.B. Simpson, "J. Stuart Anderson, Lawyers and the Making of English Land Law" (1993) 56 M.L.R. 608 .

${ }^{2}$ Offer, Property, pp. $2,84$.
} 
Benthamite liberals, and "the baddies", the solicitors' profession. ${ }^{3}$ Offer's evidence that the Benthamite liberals were defeated was sound; the 1925 legislation gave them little of what they wanted. What is and always was questionable was Offer's insistence that this defeat was a bad thing and was solely due to "the vested interest of" solicitors. ${ }^{4}$

Stuart Anderson was trained as a lawyer, not an historian; his first monograph, published in 1992, was “a sustained ... polemic against Offer's thesis of a self-seeking legal profession defeating law reform in order to protect its monopolist income." Refuting Offer's claims about lawyers, in painstaking detail, meant remaining within the same frame: focused on the solicitors' profession and over a long period, rather than on the 1925 Acts and the development of specific aspects of the law they contain. The latter would have contributed to the most important analysis left undone: thoroughly reconsidering the framework, including Offer's political/ethical judgements. Instead, the successful resistance to the market liberals' schemes was still described as "sabotage"; 6 Anderson seemed simply to replace "Offer's hard-edged picture with a nuanced alternative". 7

One would have expected Offer's and Anderson's chapters on the 1925 legislation to be followed by further research on its history; yet these remain the only two serious historical studies. Anderson became primarily interested in the nineteenth century, eventually co-authoring the 1820-1914 volumes of The Oxford History of the

\footnotetext{
${ }^{3}$ Simpson, p. 609; Getzler, pp. 684-685.

${ }^{4}$ Offer, Property, p. 84.

${ }^{5}$ Getzler, p. 685; J.S. Anderson, Lawyers and the Making of English Land Law, 1832-1940 (Oxford 1992).

${ }^{6}$ Anderson, Lawyers, p. 323.

${ }^{7}$ Getzler, p. 688; cf. Simpson.
} 
Laws of England. ${ }^{8}$ Offer never again ventured into legal history, and his political/ethical views changed: his most recent book is an attack on "market liberalism, a political and social movement that ... holds up buying and selling as the norm for human relations and for social organization", decrying its revival since the 1970s. ${ }^{9}$ He does not appear to have revisited his first monograph and re-evaluated the 1925 Acts in light of his current views.

The result of such re-evaluation is obvious. For anyone even sceptical about market liberalism, it is a good thing that the 1925 legislation does not simply embody that mentality but on the contrary largely embodies resistance to it. This thought then prompts consideration of the historical context. Developments in the common law very often do not reflect the political trends of their times or the political views of judges, due to the nature of the common law as a system: focused on resolving a particular dispute by evaluating the parties' past conduct, on grounds which must be justified in terms of "consistency in the law and fidelity to its past". ${ }^{10}$ By contrast, legislation is law made in Parliament by politicians, people whose job is to express their political beliefs through "making policy for the future" and for the nation as a whole; legislation is the stuff of political history. ${ }^{11}$

In 1905, Dicey described the struggles since the 1860 s over legislative landlaw reform as being between Benthamite liberalism and "socialism", while regretting

\footnotetext{
${ }^{8}$ W. Cornish et al, The Oxford History of the Laws of England (Oxford 2010), vols XI and XII.

${ }^{9}$ A. Offer and G. Söderberg, The Nobel Factor: The Prize in Economics, Social Democracy and the Market Turn (Princeton 2016), 1.

${ }^{10}$ M. Lobban, “The Politics of English Law in the Nineteenth Century', in P. Brand and J. Getzler (eds), Judges and Judging in the History of the Common Law and Civil Law (Cambridge 2012), 111112.

${ }^{11}$ Lobban, e.g. pp. 111, 123-124.
} 
that mainstream Liberalism had turned against the former and "philanthropic Toryism" had "a good deal of essential sympathy" with the latter. ${ }^{12}$ Early twentiethcentury "commentators like ... Dicey were fighting in the last ditch to resuscitate the ideas of mid-Victorian individualism", and their situation did not improve soon. ${ }^{13}$ The accepted view of historians is that the political-cultural force of market liberalism declined from around 1880, against the successively rising forces of socially minded New Liberalism, Labour, and "one nation" Conservatism, and did not revive until the 1970s. ${ }^{14}$ It was always unlikely that the market liberals' version of land-law reform would succeed in the 1920s.

However, 1981 also saw the publication of a new land-law textbook for undergraduates, by Gray and Symes. ${ }^{15}$ They expressly opposed market liberalismand presented the 1925 legislation as incarnating it. In an early review, Anderson pointed out that this presentation ignored not only Offer's work but all actual historical research. ${ }^{16}$ Instead, there was a "grossly ... distorted" story in which market liberalism became dominant in the late nineteenth century, its "keystone" was the 1925 legislation, and it only encountered serious challenge from the $1960 \mathrm{~s}$; "to paint the 1925 legislation as antipathetic", to make it fit this story, key provisions were ignored and "recent decisions" which in fact applied those provisions were said to

\footnotetext{
${ }^{12}$ A.V. Dicey, "The Paradox of the Land Law" (1905) 21 L.Q.R. 221, 226-227 and 232.

${ }^{13}$ M. Pugh, State and Society: A Social and Political History of Britain since 1970, 4th ed. (London 2012), 127; cf. S. Anderson, “Land Law Texts and the Explanation of 1925” [1984] CLP 63, 67.

${ }^{14}$ E.g. M. Pugh, The Making of Modern British Politics 1867-1939 (Oxford 1982); P. Clarke, Hope and Glory: Britain 1900-2000 (London 2004); Pugh, State; J. Vernon, Modern Britain: 1750 to the Present (Cambridge 2017); cf. Lobban, pp. 113-114.

${ }^{15}$ K. Gray and P. Symes, Real Property and Real People (London 1981).

${ }^{16}$ S. Anderson, "Explaining Land Law” (1982) 45 M.L.R. 346, 348-350.
} 
prove "a revolution in legal thought". ${ }^{17}$ This textbook, and its successor by Gray, became "beloved of" law students, ${ }^{18}$ doubtless in large part because this was such a simple and stirring story: cold old land law, obsessed with "exchange value", only very recently confronted by "humane ... souls" defending the "use value" needed by "real people". 19

This story was much more influential than Offer's or Anderson's research; the 1925 legislation is now commonly portrayed as embodying market liberalism, ${ }^{20}$ especially in academic writing about overreaching. Section IV below discusses overreaching in detail; for now, suffice to say that overreaching appears to fit market liberalism, prioritising ownership and trade, while constraints on overreaching fit with concern for other rights in land. Overreaching is nowadays known primarily via s.2(1)(ii) LPA 1925, concerning overreaching by trustees of land. ${ }^{21}$ In an illuminating article, Matthew Conaglen analysed academic reactions to Williams \& Glyn's Bank v Boland. $^{22}$ Mrs. Boland, who held a beneficial interest in land, won by "a commonsense application of the ordinary meaning of" the 1925 legislation. ${ }^{23}$ At first, most academic commentators recognised this; Gray and Symes were an exception. ${ }^{24}$

\footnotetext{
${ }^{17}$ Ibid., at pp. 348-350; Gray and Symes, pp. 11-13, 16-17.

${ }^{18}$ R. Smith, "Elements of Land Law" (1990) 10 O.J.L.S. 260, 260.

${ }^{19}$ K.J. Gray, Elements of Land Law (London 1987), 802; cf. Smith, p. 260.

${ }^{20}$ e.g. L. Fox O’Mahony, "Property Outsiders and the Hidden Politics of Doctrinalism" [2014] CLP 409, 420-422; S. Gardner and E. MacKenzie, An Introduction to Land Law, 4th ed. (London 2015), 201.

${ }^{21}$ cf. C. Harpum, “Overreaching, Trustees' Powers and the Reform of the 1925 Legislation” (1990) 49

C.L.J. $277,277-278$

22 [1981] A.C. 487; M. Conaglen, "Mortgagee Powers Rhetoric" (2006) 69 M.L.R. 583.

${ }^{23}$ Conaglen, p. 592.

${ }^{24}$ Ibid., at pp 590-591; cf. Gray and Symes, p. xxx.
} 
By the turn of our century, Boland was frequently praised by academics as "judicial activism", due to stated beliefs that the 1925 legislation was solely concerned with "facilitating conveyancing" and not at all concerned with protecting equitable interests in land. $^{25}$

In 1998, Anderson warned against the risk of this mischaracterisation spreading to judges: if judges were to adopt this belief and rely on it, consciously or unconsciously, in interpretation, they would be "tacitly undoing the compromise" forced on the market liberals by Parliament. ${ }^{26}$ Two recent judgments suggest that this risk has eventuated. The established understanding of overreaching under s.2(1)(ii) was that only the sale of a freehold or leasehold or the grant of a legal charge could overreach, and only beneficial interests could be overreached. Baker v Craggs, ${ }^{27}$ however, held that the grant of any legal interest can overreach; and Mortgage Express $v$ Lambert ${ }^{28}$ held that all equitable interests can be overreached, save for a few exceptions listed in s.2(3). What is striking is that these judgments radically expand the scope of overreaching by ignoring plain wording in the Act, as though the Act's purpose were solely to facilitate conveyancing and anything in the Act which did not promote that purpose should be ignored. The effect is to revive the marketliberal version of overreaching, described in 1924 as "a FRANKENSTEIN", which was defeated in Parliament. ${ }^{29}$ The High Court's result in Craggs has now been reversed by

\footnotetext{
${ }^{25}$ Conaglen, pp. 583-584.

${ }^{26}$ S. Anderson, "The 1925 Property Legislation: Setting Contexts", in S. Bright and J. Dewar (eds), Land Law: Themes and Perspectives (Oxford 1998), 128.

${ }^{27}$ [2017] 2 W.L.R. 1483.

${ }^{28}$ [2017] Ch. 93.

${ }^{29}$ See Section IV.B and n 132 below.
} 
the Court of Appeal ${ }^{30}$ but on unsustainable reasoning, and in Lambert regrettably there was no application for permission to appeal to the Supreme Court; so the monster remains at large.

\section{B. The Structure of This Article}

Section II sets out s.2(1)(ii), highlights some basic features, and states the two key questions it raises: what transactions can overreach, and what interests can be overreached?

Section III considers the answer to the first question given in Craggs in the High Court, which relied on s.1(4) LPA 1925. There is no previous authority or research on s.1(4), and it clearly contradicts the very well-known s.1(1). The High Court applied s.1(4) without even recognising this contradiction; the Court of Appeal, in order to apply s.1(1), refused to confront the contradiction and also ignored binding authority. The Parliamentary history explains the contradiction. Section 1(4) was an accident, not the first found in this Act, ${ }^{31}$ revealing one side of the history of the 1925 legislation: some issues were thoroughly debated, but outside those enclaves was chaos. Parliament expressly recognised that the 1925 legislation contained many errors and expected the court and practitioners to deal with them in light of what was then widely known about the legislation's history. When we approach the Act with this understanding, we find reasonable grounds for the Court of Appeal's result in

\section{Craggs.}

\footnotetext{
${ }^{30}$ Baker v Craggs [2018] 3 W.L.R. 401.

${ }^{31}$ See e.g. F.A.R Bennion, Understanding Common Law Legislation: Drafting and Interpretation (Oxford 2001), 47-48; Beswick v Beswick [1968] A.C. 58.
} 
Section IV turns to the second question, what interests can be overreached under s.2(1)(ii). The answer given in Lambert overlooked both binding authority and the wording of ss.2(1)-(3). In deciding whether the established pre-Lambert answer is right, existing doctrinal research is reinforced by research on the legislative history of ss.2(1)-(3) and their subsequent interpretation. This shows the other side of the history of this legislation. Whereas s.1(4) barely changed from its first incarnation in 1920, apparently due to no one noticing it - except, fleetingly, a perplexed barrister MPthe forerunners of s. 2 received a great deal of attention from 1920 on; this both led to a series of changes in the overreaching provisions and meant that ss.2(1)-(3) were well understood in 1925 . The history of their interpretation thereafter is a history of loss of legal-cultural memory, culminating in Lambert.

\section{SECTION 2(1)(ii): TWO KEY QUESTIONS}

To understand the history of s.2(1)(ii), we must start with its current full wording:

“(1) A conveyance to a purchaser of a legal estate in land shall overreach any equitable interest or power affecting that estate, whether or not he has notice thereof, if - ...

(ii) the conveyance is made by trustees of land and the equitable interest or power is at the date of the conveyance capable of being overreached by such trustees under the provisions of sub-section (2) of this section or independently of that sub-section, and the requirements of section 27 of this Act respecting the payment of capital money arising on such a conveyance are complied with”. 
This is slightly amended from the original 1925 Act; the original wording and the amendments are discussed below but, to foreshadow, do not affect the issues considered here. We should also remind ourselves, as this will become relevant in Section IV below, that s.2(1) deals with "conveyance[s] to a purchaser of a legal estate" in four different contexts; the opening words of s.2(1) are qualified by each of sub-subsections (i)-(iv), dealing with conveyances made respectively under the Settled Land Act 1925, by trustees, by mortgagees or personal representatives, and by court order.

The two key questions with regard to s.2(1)(ii) are: what sort of transaction is capable of overreaching, and what sort of interests are capable of being overreached? Although Craggs came after Lambert, Craggs will be considered first, as it primarily addressed the first question.

\section{WHAT TRANSACTIONS CAN OVERREACH UNDER S.2(1)?}

\section{A. $\underline{\text { Craggs }}$}

Mr. Craggs purchased a freehold ("the Farm") from the Charltons. The sale was completed in January 2012 but, through errors made by the Charltons' solicitors and the Land Registry, the transfer was not registered until May $2012 .^{32}$ Between those dates, the Charltons contracted to sell the Bakers another freehold and included the grant of an easement over the Farm, and this transfer and the easement were

\footnotetext{
${ }^{32}$ Craggs [2017] 2 W.L.R. 1483 at [5]-[6]; J. Farrand and A. Clarke, “Cited but not read?” (2017) 80 E.F.T.B. 1,3 .
} 
registered. ${ }^{33}$ Naturally, a dispute arose between the Bakers and Mr. Craggs. It was agreed that, between completion and registration of the transfer of the Farm, the Charltons were trustees of the Farm and Mr. Craggs held the beneficial interest. ${ }^{34} \mathrm{Mr}$. Craggs was in actual occupation, so his interest would override the easement unless the easement overreached. ${ }^{35}$

Newey J., as he then was, held that the easement overreached Mr. Craggs's interest due to s.1(4):

“section 1(4) explains that the 'estates, interests, and charges' authorised to subsist or to be conveyed or created at law by the section are referred to in the Act as 'legal estates'. The definition thus extends to the various interests ... specified in section 1(2)., ${ }^{, 36}$

He therefore held that the grant of the easement was "[a] conveyance to a purchaser of a legal estate" within the meaning of s.2(1). As described in the judgment, counsel for Mr. Craggs resisted this conclusion simply by submitting that "[o]verreaching ... is the process by which equitable interests under a trust of land are converted to interests in the sale proceeds when that land [emphasis in original] is sold to a third party purchaser". The judge merely repeated that, in s.1(4), “'legal estate' is defined in such a way as to include an easement". ${ }^{37}$

\footnotetext{
${ }^{33}$ Craggs [2017] 2 W.L.R. 1483 at [7]-[8]

${ }^{34}$ Ibid., at [10(i)].

${ }^{35}$ Ibid., at [23].

${ }^{36}$ Ibid., at [27].

${ }^{37}$ Ibid., at [31]-[32].
} 
Finally, there was the second key question, whether Mr. Craggs's interest was capable of being overreached. Counsel for Mr. Craggs relied on s.2(3)(iv), which “excepts from overreaching under section 2(2): 'The benefit of any contract ... to convey or create a legal estate"; the issue debated was whether Mr. Craggs "had an 'estate contract"' at the relevant time, and the judge held he did not. ${ }^{38}$ The judge and both counsel apparently took for granted that ss.2(2)-(3) applied to this case; and, in the Court of Appeal, there was no challenge on this point. ${ }^{39}$ We will return to it in Section IV.

The decision that the transactions capable of overreaching under s.2(1), any "conveyance to a purchaser of a legal estate", included the conveyance of a legal interest was "surprising" to doctrinal lawyers; indeed "[t]o say this is surprising, does not quite capture the sentiment." ${ }^{40}$ As is well known, s.1(1) LPA 1925 states:

"The only estates in land which are capable of subsisting or of being conveyed or created at law are-

(a) An estate in fee simple absolute in possession;

(b) A term of years absolute."

Section 1(2) then lists the interests and charges capable of subsisting or being created at law, e.g. "[a]n easement" and "[a] charge by way of legal mortgage".

The problem is that ss.1(1)-(2) are followed by s.1(4):

\footnotetext{
${ }^{38}$ Ibid., at [34], [45].

${ }^{39}$ Craggs [2018] 3 W.L.R. 401, at [21].
} 
"The estates, interests, and charges which under this section are authorised to subsist or to be conveyed or created at law are (when subsisting or conveyed or created at law) in this Act referred to as "legal estates"”.

At first glance, s.1(1) and s.1(4) seem flatly contradictory. On a closer look, they can be reconciled in only one way: per s.1(1), only the fee simple and the term of years can be legal estates; per s.1(4), the Act will refer to many other things as "legal estates" even though they cannot be legal estates. This would be absurd-if s.1(4) were taken to mean that, throughout the Act, "legal estate" would always be used to mean "legal estates, interests, and charges" and would never be used to mean what s.1(1) defines as real legal estates.

With the definition given in s.205(1)(x), the mystery deepens:

“'Legal estates' means the estates, interests and charges, in or over land (subsisting or created at law) which are by this Act authorised to subsist or to be created as legal estates".

Given that, by s.1(1), only the fee simple and the term of years are "authorised to subsist or be created as legal estates", this definition seems to contradict s.1(4); it is baffling that "interests and charges" are mentioned in this definition at all.

The Court of Appeal allowed Mr. Craggs's appeal on reasoning that was rather brief and very surprising, on interpretation and principle. On interpretation, Henderson L.J., with whom Patten and Flaux L.JJ. simply agreed, noted that s.1(1)

\footnotetext{
${ }^{40}$ M. Dixon, "The Registration Gap and Overreaching" [2017] Conv. 1, 3-4; G. Owen, "Priorities and Registered Land During the Registration Gap" [2017] Conv. 230.
} 
uses the phrase "estates in land" and s.2(1) uses the phrase "estate in land". "Accordingly," s.1(1) applied. ${ }^{41}$ He admitted that s.2(1) also uses the phrase "legal estate", which is "a defined expression", but said this definition did not apply and s.1(1) did because s.2(1) must be "read in its context", namely that s.2(1) comes "immediately after section $1[\mathrm{sic}] "{ }^{42}$ At this point in his reasoning, Henderson L.J. clearly forgot that the problematic definition of "legal estate" is in s.1(4).

Henderson L.J. further argued that, "[i]f the draftsman (Sir Benjamin Cherry) had intended section 2 to extend to the grant of a legal easement, he would surely have made this clear." ${ }^{43}$ But, if one applies s.1(4), it is clear; the fact that we have both s.1(1) and s.1(4), and no indication in s.2 of which applies, demonstrates that Cherry cannot have been both the sole and a perfect drafter. Henderson L.J. then cited three authorities saying that s.1(1) meant there were only two legal estates; but none of these mentioned s.1(4) or concerned a remotely similar issue. ${ }^{44}$ He next responded to a point made by counsel for the Bakers, that s.2(1)(ii) has always been applied to the grant of a legal charge. Henderson L.J. rightly raised s.87, giving legal chargees "the same protection ... as if" they had been granted a lease. ${ }^{45}$ The fact that legal charges fall within s.1(4) for all purposes and also within s.1(1) for some purposes, like overreaching, is of little use in deciding which definition applies to s.2(1).

Henderson L.J.'s final argument on interpretation was that, even if s.1(4) applied, overreaching would not occur in this case. He noted that s.2(1) says a relevant conveyance overreaches "any equitable interest ... affecting that estate". He

\footnotetext{
${ }^{41}$ Craggs [2018] 3 W.L.R. 401, at [24]-[27].

${ }^{42}$ Ibid., at [27]

${ }^{43}$ Ibid., at [27]

${ }^{44}$ Ibid., at [27]-[28]

${ }^{45}$ Ibid., at [29]
} 
said this "would have to mean an equitable interest in the legal estate conveyed to the purchaser, namely [if s.1(4) applied] the easement itself", and Mr. Craggs never had an equitable interest in the easement. ${ }^{46}$ But an equitable interest "affecting" $\mathrm{X}$ does not "have to mean" an equitable interest "in" X, as Henderson L.J.'s result shows: Mr. Craggs did not have any equitable interest in the easement, but his equitable interest in the Farm powerfully affected the easement, by overriding it.

Henderson L.J. had however begun his judgment by relying on principle. He asserted that "problem[s] ... of priorities" have "nothing to do with overreaching, which is a process whereby a purchaser of land takes the land free of any equitable interests which affect it, and those interests are instead transferred to the proceeds of sale. ${ }^{477}$ He returned to this statement of principle at the end of his judgment: there were no relevant proceeds of sale in this case - attributing part of the price paid by the Bakers, for their freehold and easement, to the easement was a "conceptual impossibility"- so overreaching could not have occurred. ${ }^{48}$ Remarkably, although counsels' skeleton arguments had referred to State Bank of India $v$ Sood, $^{49}$ it is not mentioned in Henderson L.J.'s judgment. ${ }^{50}$ The defendants in Sood relied on the same definition of overreaching as Henderson L.J., and the Court of Appeal in Sood unanimously rejected it. They held, as ratio, that "overreaching is the process whereby existing interests are subordinated to a later interest or estate", having nothing

\footnotetext{
${ }^{46}$ Ibid., at [31]

${ }^{47}$ Ibid., at [3].

${ }^{48}$ Ibid., at [32].

${ }^{49}$ [1997] Ch 276.

${ }^{50}$ Craggs [2018] 3 W.L.R. 401, 402D.
} 
necessarily to do with proceeds of sale; and the House of Lords refused leave to appeal. $^{51}$

All we learn from the Court of Appeal's judgment in Craggs is that these three particular judges believed s.1(1) ought to apply to s.2(1). The reasoning is so untenable as to invite further attempts to resurrect s.1(4) in relation to overreaching, and to require a future Court of Appeal or the Supreme Court to resolve, in particular, the conflict with Sood.

\section{B. The Origins of ss.1(1) and 1(4)}

The strange co-existence of ss.1(1) and 1(4) can only be understood when we realise that the LPA 1925 is a palimpsest: it emerged from and still bears traces of nearly a century of struggle between different visions of English land law. ${ }^{52}$ The height of the battle was in 1920 to 1924 , and it led to an almighty muddle in which a superseded provision in a 1921 Bill ended up as s.1(4) LPA 1925.

\section{The 1919 Report and the 1920 Bills}

In November 1919, a committee established by Lloyd George's Government to consider questions of property law published its Fourth Report; its chairman, Leslie Scott $\mathrm{KC}$, had practised in commercial and maritime law and admitted to having no

\footnotetext{
${ }^{51}$ Sood [1997] Ch 276, 281D; [1997] 1 W.L.R. 1568.

${ }^{52}$ Offer, Property; Anderson, Lawyers; Cornish, vol XII pt I chs II and V.
} 
expertise in property law. ${ }^{53}$ The declared aim was "[t]he assimilation of the Law of Real Property to that of Personal Property". ${ }^{54}$ The Report made recommendations said to be embodied in the attached Bill. Although the Report often refers to the Bill as "Mr. Cherry's", Cherry's original draft had been heavily amended to reflect "suggestions and criticisms" by other members of the committee. ${ }^{55}$ The result was described thus:

“The main principles of Mr. Cherry's Law of Property Bill may be stated broadly to be:-

(a) To assimilate the law of freeholds and copyholds to that of leaseholds ...

(b) To provide that the only estates, interests or charges which, after the Bill becomes operative, shall be subsisting or capable of being created at law, shall consist of-

i) an estate in freehold land in fee simple;

ii) a term of years absolute;

(iii) a like estate or term in mines and minerals ...;

(iv) a perpetual rent charge ...;

\footnotetext{
53 "Fourth Report of the Acquisition and Valuation of Land Committee on the Transfer of Land in England and Wales", Cmd 424, (1919) HCP xxix 89; P.A. Landon, "Scott, Sir Leslie Frederic (18691950)", rev. M. Brodie, Oxford Dictionary of National Biography (Oxford, online ed. 2008); HC Deb vol. 155 col 709 (16 June 1922).

${ }^{54}$ Fourth Report, p. 21.

${ }^{55}$ Ibid., at pp. 12, 35, 37.
} 
(v) a rent charge held for a term of years absolute;

(vi) an easement, right or privilege in or over land for an interest equivalent to a like estate or term;

(vii) any charge secured by a legal term of years absolute.

Such estates will be legal estates, and all other estates, interests and charges will take effect in equity only, and will be known as equitable interests.

(c) To place all interests in land except legal estates in fee simple, or for a term of years absolute, behind a curtain consisting of either a trust for sale or a settlement". 56

To labour the obvious, (b) and (c) are difficult to reconcile.

The Bill was published in February $1920 .^{57}$ It was never included in the published volumes of the Parliamentary Papers, probably due to the combination of its swift demise, described below, and its size -275 pages. ${ }^{58}$ The latter points to a crucial fact for understanding the development of the LPA 1925. Its forerunners, from the original 1920 Bill down to and including the Law of Property (Amendment) Act 1924, were gargantuan, far larger than the norm: each attempted to cover, in one Bill or Act, territory covered by the six property Acts of 1925 plus the complex matters relating to copyhold. This not only created a high risk of errors in drafting and scrutiny purely due to size; it also meant that the debate described in Section IV was

\footnotetext{
${ }^{56}$ Ibid., at p. 11 .

${ }^{57}$ (1920) HLP v 323.
} 
just one of a number of controversies, e.g. about registration and about copyhold, surrounding these huge bills and making it likely that other problems would be overlooked.

The minister responsible for the Bill was Lord Birkenhead, who had been Scott's pupil and also had no expertise in property law. ${ }^{59}$ The purpose of the Bill was declared in the first line of its Memorandum: "This Bill will effect a greater simplification in the practice of conveyancing ... than any measure hitherto proposed". ${ }^{60}$ Presenting the Bill to the House of Lords, Birkenhead described it as entailing "only one ... alteration" in the substance of the law, "namely, the law of succession on intestacy", and otherwise merely making "[i]mprovements in the machinery of the law". ${ }^{61}$ A key feature of these "improvements", he said, was that there would be only two legal estates, "estates in fee simple and estates for a definite term of years", and everything else would be under a trust. ${ }^{62}$

Three of their Lordships responded at length. Viscount Cave had long practised at the Chancery Bar, including as a conveyancer; he emphasised that he was "favourably disposed towards" many of the proposals in the Bill. ${ }^{63}$ Nonetheless, he expressed "great doubt" as to other aspects, including the idea of placing all interests

\footnotetext{
${ }^{58}$ J. Johnson, "Bibliography of the New Property Acts (Annotated), 1896-1925" (1926) 42 L.Q.R. 67, 80, cf. 70-71.

${ }^{59}$ Landon; J. Campbell, "Smith, Frederick Edwin, First Earl of Birkenhead (1872-1930)", Oxford Dictionary of National Biography (Oxford, online ed, 2015).

${ }^{60}$ (1920) HLP v 323, i.

${ }^{61}$ HL Deb. vol. 39 cols 254 and 256 (3 March 1920).

${ }^{62}$ HL Deb. vol. 39 col. 258 (3 March 1920); cf. Anderson, Lawyers, pp. 291-292.

${ }^{63}$ T.S. Legg and M.-L. Legg, "Cave, George, Viscount Cave (1856-1928)", Oxford Dictionary of National Biography (Oxford, online ed. 2011); HL Deb. vol. 39 cols. 270-271 (3 March 1920).
} 
in land other than the fee simple and the term of years under a trust. ${ }^{64}$ The other two significant speeches were from Viscount Haldane and Lord Phillimore; both expressed support for the Bill yet also expressed agreement with some of Cave's concerns about the basic framework. ${ }^{65}$

Birkenhead's closing speech dismissed these concerns and ended by indicating that they would be ignored in Committee; and so it proved. ${ }^{66}$ In response, Cave tabled an amendment to delete the whole of Part I of the Bill, all 34 clauses of it. Birkenhead was forced to announce that, after discussing the matter with Cave and others, "I have decided to take the course of assenting to the Amendment" and then "having further discussions". ${ }^{67}$ The remainder of the Bill was then debated and heavily amended. ${ }^{68}$

Yet something very odd was going on. Although Birkenhead told the House that, under the Bill, the only legal estates would be the fee simple and the term of years, Clause 2 read:

“(1) The only estates, interests or charges in or over land which, after the commencement of this Act, shall be capable of subsisting or of being created at law shall consist of-

(a) An estate in freehold land, in fee simple ...

(b) A term of years absolute ...

(c) A like estate or term in mines and minerals ...

\footnotetext{
${ }^{64}$ HL Deb. vol. 39 cols. 271-272 (3 March 1920).

${ }^{65}$ HL Deb. vol. 39 cols. 264-267 and 275 (3 March 1920).

${ }^{66}$ HL Deb. vol. 39 col. 280 (3 March 1920); "Report and Proceedings of the Joint Select Committee on the Law of Property Bill (H.L.)”, Parliamentary Papers (1920) vol. VII: 529 (131), 3 para 2.

${ }^{67}$ HL Deb. vol. 41 cols. 486-487 (26 July 1920); cf. Anderson, Lawyers, pp. 297-298.

${ }^{68}$ HL Deb. vol. 41 cols. 491-529 (26 July 1920).
} 
(d) A perpetual rentcharge ...

(e) A rentcharge ... for a term of years absolute :

(f) An easement, right, or privilege in or over land for an interest equivalent to a like estate or term :

(g) Any charge secured by a legal term of years absolute ...

(h) Land tax, tithe rentcharge, and any other charge on land which is not created by an instrument.

And all other estates and interests in or over land which were, at the commencement of this Act, legal estates or interests are hereby converted into equitable interests. ...

(3) The estates and interests which under this section are authorised to subsist or to be created at law are (when subsisting or created at law) in this Act referred to as 'legal estates' ..."

Clause 2(3) is substantially the same as s.1(4) LPA 1925; but Clause 2(1) is obviously very different from s.1(1) LPA 1925, and there is no equivalent of s.1(1) anywhere in the 1920 Bill.

Further, Clauses 2(1) and 2(3) were consistent with Clause 175(13) in the general-definitions section:

“'Legal estates' mean the estates and interests in land (subsisting or created at law) which are by this Act authorised to subsist or to be created at law". 
The only amendment to these clauses made in Committee was to add rights of entry to the list in Clause 2(1). ${ }^{69}$ Thus the 1920 Bills were internally consistent in their definition of "legal estate" but inconsistent with what Parliament was told, and with a published description of the original Bill written by one of its drafters. ${ }^{70}$

\section{From the 1921 Bill to the 1922 Act}

The Law of Property Bill 1921 had "a completely remodelled Part I" but kept the old Clauses 2(1) and 2(3), with minor amendments, as Clauses 1(1)-(2). ${ }^{71}$ In particular, Clause 1(2) now had exactly the same wording as s.1(4) LPA 1925. The definition of "legal estates" in the general-definitions section remained unchanged. The 1922 Bills $^{72}$ contained various amendments of the 1921 Bill but not to Clauses 1(1)-(2) or the definition of "legal estates" in the general-definitions section.

Yet the Memorandum to the 1921 and 1922 Bills stated:

"Interests in land will ... become divisible into two classes. First, the 'legal estate' in fee simple or for a term of years absolute; and, secondly, 'equitable interests,' which will include all other interests in land."73

Further, by 1922 the Bills were no longer internally consistent in their use of "legal estate": for example, Clause 7(3), which was introduced in the 1921 Bill and became

\footnotetext{
${ }^{69}$ Parliamentary Archives, HL/PO/JO/10/10/666/161, 3.

${ }^{70}$ A. Underhill, "Lord Birkenhead's Law of Property Bill” (1920) 36 L.Q.R. 107, 109.

${ }^{71}$ Johnson, "Bibliography”, p. 71; (1921) HCP ii 101 (134), 1-2.

72 (1922) HCP ii 1 (83) and 359 (145).

${ }^{73}$ Law of Property Bill 1921, iii; Law of Property Bill 1922 (83), xxv.
} 
s.7(3) Law of Property Act 1922, referred to "any contract ... for the sale of a legal estate or of an interest in land capable of subsisting at law", emphasis added. The italicised phrase makes clear that "legal estate" is not being used in accordance with the express definition in the Bills; it seems that, unsurprisingly, at least one of the drafters at least some of the time was influenced by the repeated statements that the fee simple and the term of years would be the only legal estates.

Then in 1922, again, Parliament was told by the responsible Minister something different from what Clauses 1(1)-(2) actually said; this time the statement was made in the House of Commons. In Scott's introductory speech for the Second Reading, he told the House:

"The Bill reduces legal estates in land ... to two, namely, the absolute fee simple and a term of years. ... The reduction of legal estates to two is a farreaching reform" ${ }^{74}$

Only one person seems to have noticed that this was not what the Bill said.

Many speakers in the ensuing debate expressed concerns that the Bill was so vast and complex that it had been poorly scrutinised; Scott himself told the House it was "the biggest Bill ever introduced into Parliament, and its very bulk appals." 75 An experienced solicitor MP emphasised that "this is a Bill of immense magnitude, and it is difficult to find anyone ... who really understands it. It has chaos and complication

\footnotetext{
${ }^{74}$ HC Deb. vol. 154 cols. 94-95 (15 May 1922).

${ }^{75}$ HC Deb. vol. 154 cols. 89-90 (15 May 1922).
} 
galore." "76 Another MP said that, although he expected the Bill would pass, "it will be a great act of receptive faith"; the Bill was described, quoting Milton, as "[t]he dark unbottom'd infinite abyss". ${ }^{77}$

Finally, after nearly five hours of debate, G.F. Hohler K.C. spoke:

"I have endeavoured personally to master [this Bill], and all I can say is I wish there had been some Chancery counsel a Member of this House who could have explained it. ... I understand that the principle of the Bill is to limit legal estates to a term of years absolute or to a fee simple in possession. We are told that an easement is a legal estate. ... You cannot have an easement in gross as this Clause seems to suggest."78

This was however only a brief comment in the midst of many other criticisms. Hohler had arrived late, so had not heard Scott's opening speech, and left early, so was not there to hear Scott's closing speech, inviting Members to send him any suggestions. ${ }^{79}$

No relevant amendment seems to have been proposed. ${ }^{80}$ At Third Reading fears were again expressed as to confusion about the 1922 Bill, even in Committee:

"[T]he lay members ... came to the Committee thirsting for information, but they were reduced, in the course of a few hours, to a state of hopeless

\footnotetext{
${ }^{76}$ HC Deb. vol. 154 cols. 129-130 (15 May 1922); A.G.M. Hesilrige (ed.), Debrett's House of Commons and the Judicial Bench (London 1922), 21.

${ }^{77}$ HC Deb. vol. 154 cols. 151-152 (15 May 1922); Paradise Lost, Book 2, lines 404-405.

${ }^{78}$ HC Deb. vol. 154 cols. 164-165 (15 May 1922).

${ }^{79}$ HC Deb. vol. 154 cols. 174-175 (15 May 1922).

${ }^{80}$ HC Deb. vol. 155 cols. 383-463 (14 June 1922).
} 
helplessness, and ... the legal members of the Committee did not understand the Bill very much better. ... When [ordinary lawyers] come to read [the 1922 Act $]$... [t]here will be curses both loud and deep" ${ }^{81}$

\section{From the 1922 Act to the 1924 Act}

This prediction came true; lawyers at the time described the 1922 Act as a "mangled system" which would require several years "to revise this patch-work of incongruities". ${ }^{82}$ It was passed in June 1922; the LPA 1925 was passed in April 1925. The period inbetween was one of extraordinary political upheaval, with three general elections and five Governments, under Liberal, Conservative, and Labour Prime Ministers. ${ }^{83}$ This was not a propitious time to be pursuing legislation "on a scale never before attempted" in a complex area of law. ${ }^{84}$

The 1922 Act was stated to come into force on 1 January 1925. In the Conservative Government after the 1922 election, Cave was Lord Chancellor; he appointed a Chancery judge, Romer J., to the role of Hercules in cleansing these Augean stables, chairing a committee of six drafters. ${ }^{85}$ Then there was another general

\footnotetext{
${ }^{81}$ HC Deb. vol. 155 cols. $712-714$ (16 June 1922).

${ }^{82}$ Anon, "Passing the Law of Property Bill” (1922) 57 L.J. 215, 216.

${ }^{83}$ See e.g. Clarke, ch. 4.

${ }^{84}$ W.S. Holdsworth, "The Reform of the Land Law: An Historical Retrospect” (1926) 42 L.Q.R. 158, 158; Anon, "Passing", p. 215.

${ }^{85}$ HC Deb. vol. 179 col. 498 (12 December 1924); "Report of the Committee on the Law of Property Consolidation Bills” (“Romer Report”), Cmd 2271, (1924) HCP xi 363; Legg, “Cave”.
} 
election; Haldane became Lord Chancellor under the first Labour Government. ${ }^{86}$ The Romer Committee advised that the 1922 Act and many previous property Acts required extensive amendment before being consolidated and divided into seven Acts, with only copyhold provisions remaining in the 1922 Act; they produced an "Amending Bill" and six "Consolidation Bills". 87 These were introduced to Parliament in July 1924, along with a bill to postpone the coming into force of the 1922 Act for a year. ${ }^{88}$ Then there was another general election. The new Conservative Government, like the previous Government, urged that the postponing and amending bills be passed first and fast; as the new Attorney General put it, if the 1922 Act were actually to come into force, it "would produce chaos and cause widespread disaster, if not ruin." 89 In the debate on the Law of Property (Amendment) Bill, there was no mention of the problem with which we are concerned, and the amending and postponing bills were passed in December $1924 .^{90}$

The result, the Law of Property (Amendment) Act 1924, made no changes to ss.1(1)-(2) LPA 1922, or the definition of "legal estate" in the general definitions section. The 1924 Act was described by Alfred Topham, an experienced Chancery barrister who was on the Romer Committee, as "almost impossible to understand". 91

\footnotetext{
${ }^{86}$ H.C.G. Matthew, "Haldane, Richard Burdon, Viscount Haldane (1856-1928)", Oxford Dictionary of National Biography (Oxford, online ed. 2011).

${ }^{87}$ Romer Report, pp. 2-4.

${ }^{88}$ Postponement bill: HL Deb. vol. 58 col. 540 (15 July 1924), HC Deb. vol. 176 cols 1547W (24 July 1924) and 1898 (29 July 1924); amending and consolidation bills, HL Deb. vol. 59 cols. 124-5 (31 July 1924).

${ }^{89}$ HC Deb. vol. 179 col. 1265 (18 December 1924).

${ }^{90}$ HC Deb. vol. 179 cols. 1281 and 1294 (18 December 1924).

${ }^{91}$ A. Topham, The Law of Property Acts 1925 (London 1926), 43.
} 
Nonetheless, the mammoth and chaotic 1922 Act, as amended by the nearly incomprehensible 1924 Act, was now due to come into force in little more than 12 months' time.

\section{The 1924 Bill and the 1925 Act}

The Law of Property (Consolidation) Bill ("the 1924 Bill") and its five sisters were presented to Parliament as "purely consolidating Bills". ${ }^{92}$ At the time, Parliamentary practice was "to require from those who have prepared a consolidation Bill an assurance that it will make no substantial change in the law and to have that checked by a committee. On this assurance the Bill is then passed into law". ${ }^{93}$ This explains why there was no debate on the 1924 Bill in either House. ${ }^{94}$ However, although the 1924 Act had made no amendments to either s.1 LPA 1922 or its general-definitions section, the 1924 Bill changed both: Clause 1(1) introduced what we know as s.1(1) LPA 1925, and the definition of "legal estate" in the general-definitions section introduced what we know as s.205(1)(x) LPA 1925. Yet the wording of s.1(2) LPA 1922 was kept as Clause 1(4) of the 1924 Bill and became our troublesome s.1(4).

The Romer Committee's brief report said nothing about this. In the Parliamentary Committee, no one seems to have noticed that Clauses 1(1) and 205(1)(x) contradicted Clause 1(4); there was very little, and no relevant, discussion

\footnotetext{
${ }^{92}$ HL Deb. vol. 60 col. 206 (11 February 1925).

${ }^{93}$ Beswick [1968] A.C. 58, 73E; P. Sparkes, “The 1925 Property Legislation: Curtaining Off the Antecedents" [1988] S.L.R. 146, 146-149.

${ }^{94}$ e.g. HC Deb. vol. 182 cols 1988 (6 April 1925) and 2115 (7 April 1925); Johnson, "Bibliography”, p. 71.
} 
of either Clause 1 or Clause $205 .{ }^{95}$ To be fair, the Committee were tasked with reviewing, in March 1925, all six of what became the 1925 Acts plus five other bills. Their Minutes were refreshingly frank. For example, in discussing a pair of clauses in the Settled Land Bill, one member asked a substantive question; another responded by warning, "If anybody raises the point ... [y] ou may have a debate and a fuss"; the Chairman advised, "I think we should treat it as if it were a hot potato"; and then "Clauses 102 and 103 are passed." $" 96$

The reason for the new s.1(1) is obvious. A recurring theme in discussions of reforming the law of real property had for years been the desirability of reducing the number of types of legal estate, and it had become widely accepted that there should be only two, the fee simple absolute and the term of years absolute. ${ }^{97}$ Further, as above, the minister responsible for the Bill which became the 1922 Act had expressly told Parliament that these were to be the only two legal estates, continuing a series of such statements from 1920 on, and nothing to the contrary had ever subsequently been said.

But why then was s.1(2) LPA 1922 kept as s.1(4) LPA 1925? In the apparent absence of any recorded explanation, there seem only two possibilities. The first is sheer oversight, by the drafters as well as Parliament. The second is that the drafters of the 1924 Bill deliberately included Clause 1(4) alongside Clause 1(1) because the 1922 and 1924 Acts were internally inconsistent in their use of "legal estate". As above, in some provisions the wording showed unequivocally that "legal estate" in the narrower definition was intended; but in other provisions the wording showed

\footnotetext{
${ }^{95}$ Joint Select Committee Report on the Consolidation Bills (1925) HCP vii 111, 11-12 and 39-40.

${ }^{96}$ Ibid., at p. 49.

${ }^{97}$ e.g. Holdsworth, p. 180.
} 
unequivocally that the broader definition was intended, e.g. in Sch 3 Part II para 14 of the 1924 Act, "All conveyances of land or of any interest therein are void for the purpose of conveying or creating a legal estate unless made by deed." In most cases, though, it was not immediately obvious simply from the wording of the provision which definition was meant.

Ideally, the drafters of the 1924 Bill, having by Clause 1(1) inserted a new definition of "legal estate", would have deleted Clause 1(4) - and amended Clause 205(1)(x) more tidily - and then gone through the whole Bill, examining each provision containing the phrase "legal estate", deciding whether in that particular provision it accorded with the new definition, and, if not, deciding what to replace it with. This would have meant not only a great deal of additional work but also, given that these were supposed to be consolidating bills, further impropriety. The only other option was to put both definitions in the first section of the LPA 1925, signalling to future judges and lawyers that the use of "legal estate" in the Act was not consistent and that a decision would have to be made each time the phrase appeared as to which definition applied.

Whatever the drafters' reasons, if any, this is the only reasonable solution to the conflict between ss.1(1) and 1(4); and it seems to have been taken for granted after 1925. Practitioners were well aware of the background to the 1925 legislation, regularly reported in the legal press from 1920 on, ${ }^{98}$ and thus that problems were likely, and that these were unlikely to be highlighted in commentary written by the Acts' drafters. A review of the 1932 edition of Wolstenholme \& Cherry noted that Lincoln's Inn was "doing well out of the Acts" and added: "ideally, the standard commentary on a Statute should not be made by the draftsmen, or, if it is, ... the

\footnotetext{
${ }^{98}$ See e.g. Johnson, "Bibliography”, pp. 76-78.
} 
commentators should frankly say, when faced with a tangle, 'we meant such and such, but unfortunately we made a mess of it". 99

Practitioners' awareness of the likelihood of errors in the 1925 Acts was shared by the parliamentarians who had been most closely involved with the Acts' development. ${ }^{100}$ In 1925, at the Second Reading of the Consolidation Bills, Haldane had said "it would pass the wit of man to say whether, in the form which these Bills have finally assumed, they ... are free in all respects from error"; ${ }^{101}$ in 1926, on the Second Reading of the Bill which became the Law of Property (Amendment) Act 1926, he expressed his belief that "your Lordships will have to deal” with "ten or even twenty" such amending bills "before a very long time is passed." Cave recognised the problems with the 1925 legislation, attributed them largely to the 1922 Act, for which "I was not responsible", and accepted that the 1926 Bill was merely "to remedy the more urgent of them". Nonetheless, he emphasised that "everybody has done his utmost to facilitate the smooth working" of the legislation, and he was content "to leave doubts so far as possible to be resolved in the course of the working of the Act and through the decisions of the Courts.",102

\section{Conclusion}

Once we recover the memory of the chaotic background of the Act and accept that the Act contains errors, we are motivated to scrutinise the whole Act far more carefully-

\footnotetext{
99 "H.A.H." (H.A. Hollond), "Wolstenholme and Cherry's Conveyancing Statutes. Twelfth Edition" (1933) 5 C.L.J. 145, 145; cf. Beswick [1968] A.C. 58, 93D and 105C.

${ }^{100}$ Cf. G.C. Cheshire, “The Recent Property Legislation in England” [1926] U. Penn. L.R. 767, 767.

${ }^{101}$ HL Deb. vol. 60 col. 208 (11 February 1925).

${ }^{102}$ HL Deb. vol. 63 col. 575 (16 March 1926); HL Deb. vol. 64 col. 357 (10 June 1926).
} 
in this case, for clues as to which definition of "legal estate" applies to "purchaser of a legal estate" in s.2(1).

As noted above, the fact that the grant of a legal charge has always been viewed as within s.2(1)(ii) does not in itself help us: legal charges are expressly included in s.1(4), but the effect of s.87 is to bring legal charges also within s.1(1) for some purposes. However, s.205(1)(xxi) provides a specific definition of "purchaser of a legal estate”: “Purchaser' ... includes a ... mortgagee or other person who for valuable consideration acquires an interest in property ... and in reference to a legal estate includes a chargee by way of legal mortgage", emphasis added.

There are only two possible reasons for the italicised part of this definition. One is that the drafter had in mind the Clause 1(4) definition of "legal estate" and was merely reiterating that legal charges are included; but, if the drafter had been thinking of the Clause 1(4) definition, why would he reiterate what it clearly says? The other is that the drafter had in mind the Clause 1(1) definition of "legal estate" and wanted to pre-empt any controversy as to the effect of Clause 87 ; this seems far more likely. ${ }^{103}$ And, given what Parliament was consistently told, in the unlikely event that any parliamentarians ever read and thought about this part of Clause 205(1)(xxi), they would have understood it as meaning the "purchaser" of a fee simple absolute, term of years absolute, or legal charge.

As for our broader understanding: If Parliament had accepted the marketliberal philosophy of the 1920 Bills, the changes made between February 1920 and April 1925 could simply have focused on correcting errors. The fact that errors proliferated indicates that there was a battle but not why. The next Section illustrates that the repeated changes, starting with the decapitation of the 1920 Bill, were driven

\footnotetext{
${ }^{103}$ Cf s.11, instruments "creating a legal estate or charge by way of legal mortgage".
} 
by rejection of the market-liberal focus on facilitating conveyancing at the expense of other interests.

\section{WHAT INTERESTS CAN BE OVERREACHED UNDER S.2(1)(ii)?}

The second key question in relation to s.2(1)(ii) is best considered in the context of Lambert; Lambert was not cited in Craggs (at first instance or on appeal ${ }^{104}$ ), but both made the same error, foreshadowed above.

\section{A. Lambert}

A pair of fraudsters dishonestly told Ms. Lambert her home was worth $£ 30,000$ and said they would buy it for that price and rent it back to her; being "vulnerable [and] naïve", she agreed, and the sale was completed by the fraudsters using a bridging loan. ${ }^{105}$ The fraudsters then entered into an agreement with Mortgage Express for a loan of $£ 102,000$ secured by a charge on the flat, which was worth $£ 120,000$; the charge was completed and registered. The fraudsters defaulted on the repayments, Ms. Lambert fell into arrears with the rent, and receivers appointed by Mortgage Express applied for possession. ${ }^{106}$ Ms. Lambert counterclaimed to set aside the sale to the fraudsters. ${ }^{107}$ The judge at first instance held that Ms. Lambert had a right to have the

\footnotetext{
${ }^{104}$ Although it was included in counsels' skeleton arguments on appeal: Craggs [2018] 3 W.L.R. 401, 402D.

${ }^{105}$ Lambert [2017] Ch. 93, at [1], [3], [9].

${ }^{106}$ Ibid., at paras [2], [4], [6]-[7].

${ }^{107}$ Ibid., at p. 95A-B.
} 
sale set aside as an unconscionable bargain, and that this right was an equity, a proprietary right, but did not bind Mortgage Express; $;{ }^{108}$ Ms. Lambert appealed.

The Court of Appeal's judgment was given by Lewison L.J.; Gloster L.J. and Cobb J. simply agreed. Lewison L.J. held that the right to set aside an unconscionable bargain arose on exchange of contracts and was capable of being an overriding interest. ${ }^{109}$ However, he dismissed the appeal on three grounds, two of which have been powerfully criticised elsewhere. ${ }^{110}$ There remains Lewison L.J.'s reasoning that Ms. Lambert's equity was overreached due to s.2(1)(ii) LPA 1925. "The only ... question" was "whether Ms. Lambert's interest was 'capable of being overreached"'.111

Lewison L.J. relied first on Birmingham Midshires $v$ Sabherwal. ${ }^{112}$ But, in Mrs. Sabherwal's case, it was accepted that she had a beneficial interest under a resulting trust and that this was capable of being overreached; what Robert Walker L.J., as he then was, rejected was the notion that this result could be circumvented by claiming an estoppel equity. ${ }^{113}$ The Court of Appeal later held in Sommer $v$ Sweet, ${ }^{114}$ a decision of Sir Andrew Morritt V.C., Clarke L.J. as he then was, and Jonathan Parker L.J., that a genuine equity by proprietary estoppel was not capable of being

\footnotetext{
${ }^{108}$ Ibid., at p. $95 \mathrm{~B}$, paras [9], [11].

${ }^{109}$ Ibid., at paras [16]-[20], [23]-[24].

${ }^{110}$ M. Dixon, "Priority, Overreaching and Surprises under the Land Registration Act 2002” (2017) 133

L.Q.R. 173.

${ }^{111}$ Lambert [2017] Ch. 93, at para. [32].

112 (2000) 80 P \& CR 256; Lambert [2017] Ch. 93, at paras [34]-[36].

${ }^{113}$ Sabherwal (2000) 80 P \& CR 256, at [24].

${ }^{114}$ [2005] EWCA Civ 227.
} 
overreached, citing Sabherwal as supporting this conclusion. ${ }^{115}$ Sommer was not put before the court in Lambert; ${ }^{116}$ a future court will have to deal with the contradiction. Lewison L.J.'s fundamental reason for finding that Ms. Lambert's equity could be overreached was:

"It is clear from the opening words of [s.2(1)] that it applies to 'any equitable interest' ... Moreover the express list of exclusions from overreaching in section 2 (3) ... demonstrates that the ambit of overreaching is wide, otherwise those exclusions would not have been necessary." 117

This was the same misreading as was made in Craggs; and, as in Craggs, the judgment does not record any assistance from counsel on this point.

As noted in Section II above, the opening words of s.2(1) are limited in appropriately different ways by each of sub-subsections (i)-(iv). Section 2(1)(ii) states that the only equitable interests which can be overreached on a conveyance by trustees are those "capable of being overreached by such trustees under the provisions of subsection (2) of this section or independently of that sub-section". Subsection (2) states that it applies only where "the trustees (whether original or substituted) are either-(a) two or more individuals approved or appointed by the court or the successors in office of the individuals so approved or appointed; or (b) a trust corporation"; and subsection (3) states that it only applies in relation to subsection (2). Ms. Lambert's fraudsters were neither a trust corporation nor "approved or appointed by the court or the

\footnotetext{
${ }^{115}$ Sommer [2005] EWCA Civ 227, at [25]-[28]; cf. C. Harpum, M. Dixon, and S. Bridge, Megarry and Wade: The Law of Real Property, 8th ed. (London 2012), at [6-054] fn 173.

${ }^{116}$ Lambert [2017] Ch. 93, 94C-H.
} 
successors in office of [such] individuals", so subsections (2) and (3) were irrelevant. The plain wording of ss.2(1)(ii), 2(2), and 2(3) has been overlooked not only by the court and counsel in Craggs and Lambert but also by all bar one of the academic commentators on these cases. ${ }^{118}$

However, the fact that Lewison L.J.'s reasoning was wrong does not mean the usual understanding - that, under s.2(1)(ii) per se, only beneficial interests can be overreached - is right. The crucial question remains: What does s.2(1)(ii) mean when it refers to equitable interests "capable of being overreached by ... trustees ... independently of" subsection (2)?

\section{B. The Origins of s.2}

There is no statutory definition of overreaching; overreaching by trustees "independently of" s.2(2) can only mean overreaching as it was understood in the common law, including equity, in 1925. The statutory provisions on overreaching were a key front in the battle between different visions of land law: whereas there was no known debate about the forerunners of ss.1(1)-(4), there was a great deal of debate about the forerunners of s.2.

\section{Overreaching in equity and common law}

\footnotetext{
${ }^{117}$ Ibid., at para. [37].

${ }^{118}$ The exception is A Televantos, "Unconscionable Bargains, Overreaching and Overriding Interests" (2016) 75 C.L.J. 458, 459, which however does not proceed to the crucial question.
} 
As a number of authors have pointed out, what became known as "overreaching" by trustees is merely the necessary and unremarkable outcome of basic trust principles, where trustees have a power to dispose of trust property. ${ }^{119}$ If trustees had such a power and properly exercised it, then of course the beneficiaries would cease to have beneficial interests in the property disposed of, because it would no longer be trust property, and the beneficiaries would have beneficial interests in any property received in exchange. ${ }^{120}$ This is, or was, so obvious that nineteenth-century property and trusts textbooks do not have sections on overreaching (or "overriding", often used in the same sense $\mathrm{e}^{121}$ ) or index headings for it; it was merely used in the text, in passing, to describe the effect of the proper exercise of a power. ${ }^{122}$

Similarly, in the late eighteenth century mortgages began to be drafted to give the mortgagee a power of sale and with the mortgagor expressly agreeing that, if the power was exercised, the mortgagor would give up the equity of redemption; judges held such wording to be effective and that the proceeds of sale were held on trust, and mortgages drafted in this way became standard by the 1840 s. ${ }^{123}$ "Overreaching" was used to describe the effect but was viewed simply as the result of the agreement. ${ }^{124}$

\section{The Settled Land Act 1882}

\footnotetext{
${ }^{119}$ Harpum, "Overreaching"; D. Fox, "Overreaching”, in P. Birks and A. Pretto (eds), Breach of Trust (Oxford 2002); R. Nolan, “The Administration and Maladministration of Funds in Equity”, in P. Turner (ed.), Equity and Administration (Cambridge 2016), 74-79.

${ }^{120}$ Nolan, p. 77.

${ }^{121}$ See e.g. Joint Select Committee (1925), pp. 12-13.

122 e.g. R. Preston, An Elementary Treatise on Estates, vol. 1 (London 1820), 158.

${ }^{123}$ Megarry \& Wade at [25-013] and [25-020]; Cornish, Vol XII, pp. 135-138.

${ }^{124}$ Cornish, Vol XII, pp.137-139.
} 
Then came the Settled Land Act 1882. Before 1926, "settlements" could take two forms, a "grant to uses" or a trust; the effect however was essentially the same. ${ }^{125}$ In the nineteenth century, with huge amounts of English land held on settlement, there were concerns that settlements giving inadequate powers of sale and leasing could leave tenants for life so impecunious that they could not make improvements to the land. $^{126}$

The central feature of the 1882 Act was s.20. Tenants for life were given the power to sell or lease the land with the same effect as if they were trustees with such a power — "the land conveyed" would be "discharged from all ... estates, interests and charges subsisting or to arise" under the settlement, with stated exceptions; the proceeds would then be held on trust. Furthermore, s.51 made "contracting out" impossible. ${ }^{127}$ Overreaching as the consequence of basic trust or contractual principles was unremarkable; as a measure imposed by statute, decoupled from trust or contract, it was "a revolution". 128

\section{The 1920 Bill: "the curtain"}

\footnotetext{
${ }^{125}$ See e.g. R. Cozens-Hardy Horne, Lewin's Practical Treatise on the Law of Trusts, 15th ed. (London 1950), 520-521.

${ }^{126}$ Cornish, Vol XII, pp. 79-94.

${ }^{127}$ Megarry \& Wade at [10-006]; cf. In re Carne's Settled Estates [1899] 1 Ch. 324, 330.

${ }^{128}$ In re Duke of Marlborough's Settlement (1885) 30 Ch. D. 127, 131; J. Johnson, "The Reform of Real Property Law in England" [1925] Colum. L. Rev. 609, 611.
} 
The 1882 Act encouraged proposals by market liberals to expand by statute the types of interests capable of being overreached as well as the circumstances in which overreaching would occur. Their most ambitious proposals were in the 1920 Bills.

The first page of the Memorandum to the 1920 Bills announced, as noted above, the aim of achieving a radical "simplification in the practice of conveyancing" and then explained that this would be achieved by making many more interests in land equitable and placing all equitable interests "behind a curtain". ${ }^{129}$ The idea was striking, as was the metaphor, which was "new and picturesque". ${ }^{130}$ Weaving the curtain then took up most of the first seven pages of the Bill. Clause 3(1) said:

"Where at the commencement or by virtue of this Act land is subject, or is made subject, to a trust for sale, all estates, interests and charges in or over the same and subsisting at such commencement, which are or have by this Act been converted into equitable interests, shall attach to the proceeds of sale in like manner as if created by a trust affecting those proceeds."

Where land was subject to a trust for sale and equitable interests arose after the Act's commencement, Clause 4(1) deemed them also to be beneficial interests in the proceeds of sale. Clauses 3(3) and 4(1) had similar provisions for settled land and, if equitable interests arose in relation to land which was neither settled land nor held on trust for sale, deemed those interests to arise under a settlement. Clause 1(5) abolished the Statute of Uses, so settlements could only be trusts. Finally, Clauses 5-7 repeated the substance of Clauses 3-4 but in relation to equitable powers.

\footnotetext{
${ }^{129}$ (1920) HLP v 323, i.

${ }^{130}$ Anon, "The Report of the Land Transfer Committee" (1919-20) 64 Sol J 252, 253.
} 
In Committee, a new Clause 4(4) was added, closing a potential gap in the curtain:

"Where an equitable interest arises by way of estoppel, lien, or otherwise by operation of law, then, if the land is subject to a trust for sale, the equitable interest shall attach to the proceeds of sale in like manner as if created by a trust affecting those proceeds, but where there is no trust for sale the equitable interest shall take effect as if the same had been limited by a settlement ... [and] if a settlement is subsisting when the equitable interest arises it shall ... take effect as if limited by such settlement."131

The result has been called the "universal curtain": ${ }^{132}$ all equitable interests in land were made capable of being overreached, with only two exceptions, restrictive covenants and equitable mortgages by deposit of deeds. ${ }^{133}$ The only counterweight, in relation to trusts for sale, was the introduction of the "two-trustee rule", the requirement that proceeds be paid to two trustees or a trust corporation, based on a widespread belief that fraud by trustees usually involved an individual sole trustee. ${ }^{134}$

However, as above, the whole of Part I of the amended 1920 Bill was rejected in Parliament, due to expressed concerns including that the basic framework of the

\footnotetext{
${ }^{131}$ Parliamentary Archives, HL/PO/JO/10/10/666/161, 6.

${ }^{132}$ Anderson, Lawyers, p. 297.

${ }^{133}$ Law of Property Bill (1920) HLP v 323, Clause 3(6).

${ }^{134}$ Ibid., at pp i and 175; Anderson, Lawyers, p. 292.
} 
Bill did not adequately protect equitable interests in land, that entitlement to a sum of money was not the same and not enough. ${ }^{135}$

\section{From the 1920 Bills to the 1925 Act}

By 1925, "there is very little 'curtain' left", as contemporaries recognised. ${ }^{136}$ But the market-liberal version of overreaching was not simply killed off by the decapitation of the 1920 Bill; it took four more years.

In the 1921 Bill, there was nothing corresponding to Clause 4(4) of the amended 1920 Bill. By Clause 3(3)(i)-(ii) of the 1921 Bill, if an equitable interest arose at a time when the legal estate was subject to a trust for sale or a settlement, the interest was deemed to be capable of being overreached; by Clause 3(3)(iii), if the equitable interest arose at a time when the legal estate was not subject to a trust for sale or a settlement, there was a provision similar to s.2(2) LPA 1925. This Bill also introduced, in Clause 3(4)(v), the wording "interests ... capable of being overreached" by trustees "independently of this section". However, such interests formed part of a list of exceptions otherwise similar to those in s.2(3) LPA 1925, and the 1921 list excepted these from the operation of the whole Clause including the two-trustee rule. $^{137}$

The Memorandum to the first 1922 Bill explained that it was a response to widespread criticism of the 1921 Bill; for our purposes, the only relevant change was

\footnotetext{
135 e.g. HL Deb. vol. 39 cols. 264-265, 271-272, 275 (3 March 1920); HL Deb. vol. 41 cols. 486-487, 490-491 (26 July 1920); J. Lightwood, “Trusts for Sale” (1927-1929) 3 C.L.J. 59, 68.

${ }^{136}$ Anon, "The Law of Property Acts" (1925) 60 L.J. 461.

${ }^{137}$ Law of Property Bill 1921, Clauses 3(4) and 11, Sch 4 para 3.
} 
that beneficial interests were no longer excepted from the two-trustee rule. ${ }^{138}$ So Clause 3 of the 1922 Bills still meant that almost all equitable interests arising after the creation of a trust were deemed capable of being overreached by ordinary trustees; and it became s.3 LPA 1922.

Finally, due to continuing criticism, ${ }^{139}$ s.3 LPA 1922 was replaced by a radically different provision in the Bill which became the 1924 Act; ${ }^{140}$ this new provision became Clause 2 of the 1924 Bill and s.2 LPA 1925. Contemporary lawyers recognised that Clause 2(1) of the 1924 Bill was "entirely declaratory" of the existing law with regard to transactions made respectively (i) under the Settled Land Act, (ii) by trustees, (iii) by mortgagees or personal representatives, and (iv) by order of the court. ${ }^{141}$ Outside s.2(2), "the old law" remained in force-trustees could only overreach "the equitable rights of the beneficiaries"; ${ }^{142}$ the only change under s.2(1)(ii) was that overreaching would only occur if proceeds were paid to two trustees or a trust corporation. The contemporary understanding was thus the same as the better view among recent academics: s.2(1)(ii) "merely limit[s] the powers to overreach that [trustees] would otherwise enjoy under the general law". ${ }^{143}$

\footnotetext{
${ }^{138}$ Law of Property Bill 1922 (Bill 83): Memorandum at i-iii, Clause 3(2)-(3).

${ }^{139}$ See e.g. Law of Property (Amendment) Bill (1924) HCP ii 561, covering page; E. Harvey, The Law of Property Act 1922: How Will It Work? (London 1923), 15-39; “J.M.L.” (J. Lightwood), “The Curtain Clause" (1925) 60 L.J. 112, 113.

${ }^{140}$ Sch 3 Part II para 1 of the Bill and the Act.

${ }^{141}$ Anon, "The Law of Property Bills" (1924) 69 Sol J. \& Wkly Rep 119, 119-120.

${ }^{142}$ Cheshire, "Recent”, p. 776. Cf. G. Cheshire, The Modern Law of Real Property (London 1925), 82-

83; Lightwood, "Curtain"; Johnson, "Reform"; W. Banks, Lewin's Practical Treatise on the Law of Trusts, 13th ed. (London 1928), 1100; B. Cherry et al (eds), Wolstenholme and Cherry's Conveyancing Statutes, 12th ed. (London 1932), 232.

${ }^{143}$ Fox, "Overreaching", p. 95 fn 1.
} 
The "innovation" was Clause 2(2), now s.2(2). ${ }^{144}$ This enabled trustees to overreach equitable interests other than beneficial interests, but only if the trustees were court-approved (or successors of such trustees) or a trust corporation, the latter meaning the Public Trustee, a corporation appointed by the court, or a corporation meeting the requirements of the Public Trustee Act $1906 .{ }^{145}$ Further, s.2(3) listed equitable interests which were not capable of being overreached even under s.2(2). These constraints were necessary because, as contemporaries put it, otherwise s.2(2) would be "a FRANKENSTEIN". 146

The Law of Property (Amendment) Act 1926 made one amendment to s.2, correcting a drafting error of the type discussed above: a phrase carried over from s.3(3) LPA 1922 to s.2(2) LPA 1925 made no sense in the radically different framework of s.2 LPA $1925 .{ }^{147}$ Finally, the Trusts of Land and Appointment of Trustees Act 1996 made minor amendments to ss.2(1)-(2), but these do not expand the types of interest capable of being overreached by trustees outside s.2(2). ${ }^{148}$

\section{The Return of Frankenstein}

The misreading that occurred in Lambert, the conflation of equitable interests "capable of being overreached ... under the provisions of sub-section (2)" with those

\footnotetext{
${ }^{144}$ Anon, "Bills", p. 120; Cheshire, Modern, p. 83; Johnson, "Reform”, p. 624.

${ }^{145}$ LPA 1925, s.205(1)(xxviii).

${ }^{146}$ Anon, "Bills", p. 120, emphasis in original.

${ }^{147}$ Cf. Lightwood, “Trusts”, pp. 68-69.

${ }^{148}$ Cf. Sabherwal (2000) 80 P \& CR 256, at [22]; M. Dixon, "Overreaching and the Trusts of Land and Appointment of Trustees Act 1996” [2000] Conv. 267.
} 
capable of being overreached by trustees "independently of that sub-section", was the long-term consequence of two factors.

First, overreaching under s.2(2) was soon forgotten, because it was practically useless. Section 2(2) might seem a great gift to the holders of legal estates, but not when one considers the mechanics, as commentators quickly realised. ${ }^{149}$ Obtaining the required type of trustee before proceeding with the intended conveyance would be costly and time-consuming. For the vendor, there would also be delay after the intended conveyance in receiving the money: the trustees would have to investigate all possible equitable interests, and determine what if any share of the proceeds their holders should have, before distributing the rest to the vendor. It was much easier to stick with existing practice: if there were an inconvenient equitable interest, the vendor should obtain a discharge from the interest-holder or get his/her concurrence in the conveyance. ${ }^{150}$ Contemporaries therefore predicted that s.2(2) would rarely be used, and a recent source doubts whether it has ever been used. ${ }^{151}$

Second, overreaching “independently of” s.2(2) LPA 1925 was, paradoxically, too well understood before and for two or three generations after 1925. In 1926, a suggestion for improvement of a well-known textbook was that one might explain "what is meant by overreaching", as "[a] beginner would find it very useful". ${ }^{152}$ But so long as legal training remained primarily by apprenticeship and there were many

\footnotetext{
${ }^{149}$ For what follows, see "J.M.L.” (J. Lightwood), "Making Title” (1925) 60 L.J. 748, 748-749.

${ }^{150}$ In the form of a waiver, this remains the usual practice: Megarry \& Wade, [13-105] and fn 604.

${ }^{151}$ E.g. Lightwood, "Making”, 749; Megarry \& Wade at [12-037] fn 17. Cf. M. Lewis, "Statutory Trusts For Sale" (1940) 56 L.Q.R. 255, 257; “A.D.H.", "Reviews: A Manual of the Law of Real Property" (1947) 1 J.S.P.T.L. 57, 58.

152 "H.A.H.” (H.A. Hollond), "Book Reviews: Williams' Principles of the Law of Real Property" (1926) 2 C.L.J. 413, 413-414.
} 
lawyers around who had learned the law before 1926, budding property lawyers would learn the fundamental meaning of overreaching in articles or pupillage. ${ }^{153}$

The fact that everyone knew what s.2(1)(ii) meant by "capable of being overreached by ... trustees ... independently of" s.2(2) is reflected in the lack of authority directly on the point for over 60 years. The closest one gets, for decades, is In re Ryder and Steadman's Contract, ${ }^{154}$ in 1927. In 1924, the vendors became legal tenants in common of a freehold subject to a jointure; in 1926, they contracted to sell the freehold. It was accepted that the jointure had become an equitable interest. Counsel for the purchaser submitted that the transitional provisions of the LPA 1925 made the land settled land, or, alternatively, that s.28 expanded the overreaching powers of ordinary trustees for sale. The Court of Appeal rejected both arguments. They also rebuked the first-instance judge for relying on Wolstenholme \& Cherry regarding the transitional provisions: no "importance [was] to be attributed to the views of the writer because he may be recognized as the draftsman of the statute in question. On the contrary, that very fact may disable him from taking an unbiased view". 155

The next relevant judgment, Shiloh Spinners Ltd $v$ Harding, ${ }^{156}$ came 45 years later. Shiloh claimed an equitable right of entry in relation to Harding's lease of unregistered land. The right had arisen before the lease was assigned to Harding and had not been registered as a land charge; so, if it fell within the Land Charges Act 1925, it would be unenforceable. Counsel for Harding submitted that, for unregistered land, the 1925 legislation intended to make all equitable interests either overreachable

\footnotetext{
${ }^{153}$ J.L. Barton, "The Authorship of Bracton: Again” (2009) 30 J.L.H. 117, 127.

${ }^{154}[1927] 2$ Ch. 62.

${ }^{155}$ Ryder [1927] 2 Ch. 62, p. 84; cf. the anonymous casenote (1927) 43 L.Q.R. 441, 441-442.
} 
or registrable as a land charge; an equitable right of entry was incapable of being overreached; and therefore it must be registrable as a land charge. Counsel for Shiloh, the future Vinelott J. and Morritt V.C., supported the argument that the right was incapable of being overreached but argued against the first premise. The House of Lords held that equitable rights of entry, and some other equitable rights "such as rights ... to set aside a conveyance", might well fall entirely outside "the 'curtain' or 'overreaching' provisions of the 1925 legislation" and thus be incapable of being overreached in any circumstances; they rejected the argument that this compelled the conclusion that such rights must be registrable as land charges. ${ }^{157}$

Shiloh is noteworthy because it specifically mentions the type of right Ms. Lambert claimed - and was not cited in Lambert - and for showing five Law Lords and two future Chancery judges taking, in the 1970s, a view at the opposite end of the spectrum from Lambert: namely that some equitable rights were incapable of being overreached even under s.2(2) and even though not listed in s.2(3). Pausing to recall the discussion above regarding Sood and Sommer: we are now in a position in which the two most recent Court of Appeal judgments on overreaching contradict, without even mentioning, two prior Court of Appeal decisions and a decision of the House of Lords.

Returning to our chronology: in 1987, a case explicitly considering the meaning of "capable of being overreached by ... trustees ... independently of" s.2(2) finally arrived, City of London Building Society v Flegg; ${ }^{158}$ but the issue was whether

\footnotetext{
${ }^{156}[1973]$ A.C. 691.

${ }^{157}$ Ibid., at p. 721B-C, cf. 719C-721G.

${ }^{158}[1988]$ A.C. 54.
} 
this phrase excluded even beneficial interests in some circumstances. ${ }^{159}$ There was no suggestion that any other equitable interests were capable of being overreached outside s.2(2). Similarly, in 1988 the Law Commission defined overreaching by trustees as "when beneficiaries' interests are detached from land". ${ }^{160}$

It seems that the first attempt to argue that any other sort of interest was capable of being overreached by trustees outside s.2(2) was in Sabherwal, in 1999; as above, this argument was dismissed because the interest at issue was actually a beneficial interest. Unfortunately, there were some dicta capable of causing confusion. The court suggested obiter that "[t]he essential distinction is, as the authors of [the 1984 edition of] Megarry and Wade note, between commercial and family interests", the latter being overreachable and only some of the former not. ${ }^{161}$ This was both unnecessary and misleading, ${ }^{162}$ especially in diverting attention from the statutory provisions.

In 2005, in Sommer, for the first time an attempt was made to argue that an equitable interest which was (genuinely) not a beneficial interest could be overreached under s.2(1)(ii) "independently of" s.2(2). The point was apparently not raised at first instance, ${ }^{163}$ and, as above, the Court of Appeal rejected the argument. However, the judgment on this point is brief; understandably given his history, Morritt V.C. simply relied on Shiloh. ${ }^{164}$

\footnotetext{
${ }^{159}$ Ibid., at pp. 63G-64A, 83D-E, 86H-91B.

${ }^{160}$ Law Commission Working Paper 106, Trusts of Land: Overreaching (1988), iv.

${ }^{161}$ Sabherwal (2000) 80 P \& CR 256, at [25]-[31].

162 cf. N. Hopkins, “The Relevance of Context in Property Law: A Case for Judicial Restraint?” (2011)

31 L.S. 175.

${ }^{163}$ Sweet v Sommer [2004] EWHC 1504 (Ch).

${ }^{164}$ Sommer [2005] EWCA Civ 227, at [18] and [26].
} 
Banwaitt v Dewji, ${ }^{165}$ in 2015, marks the shift. Master Matthews, as he then was, held obiter that an equitable charge could be overreached: "Where there are two individual trustees of a trust of land, then by s 2(2) any equitable interest is capable of being overreached, unless it is of a kind excepted under s 2(3)"-emphases in original. ${ }^{166}$ This ignored the clear wording of ss.2(2)-(3) and the fact that neither the trustees in Banwaitt nor their predecessors had been "approved or appointed by the court". And now we have Lambert and Craggs.

If we had remained aware of s.2(2), the error in Banwaitt, Lambert, and Craggs could not have happened; but even Megarry \& Wade contains no mention of s.2(2). ${ }^{167}$ Thus if practitioners and judges are labouring under a misapprehension as to the nature of the 1925 Acts and do not actually read s.2(1)-(3), they can easily go wrong.

\section{CONCLUSION}

English land law has for centuries been a system which recognises that, for any given piece of physical land, a number of people may have a wide range of different interests in it which are legitimate and need to be reconciled with each other. The history of English land law is a history of attempts to find the just balance between these legitimate interests.

\footnotetext{
${ }^{165}$ [2015] EWHC $3441(\mathrm{Ch})$.

${ }^{166}$ Ibid., at [22].

${ }^{167}$ One footnote mentions "an ad hoc trust"- Megarry \& Wade, at [12-037] fn 317-but few 21stcentury readers will know that this phrase was used in the 20th century to mean a trust complying with s.2(2): see e.g. Anon, “The Law of Property Acts" (1925) 60 L.J. 461 and Shiloh [1973] AC 691, 698F and $715 \mathrm{~A}$.
} 
The history of the overreaching provisions of the LPA 1925 is the history of an attempt by some market-liberal extremists to tip the balance heavily in favour of "owners" and against those with other legitimate interests in the land. The extremists lost, and the LPA 1925 reflects that defeat. Admittedly, the reflection is in some respects through a glass darkly; the result of years of battle across a vast and difficult terrain was that some things were left undone. On the other hand, our forebears were entitled to expect that we would pay attention to what the LPA 1925 actually says, and that we would remember the history which the Act on careful reading shows that we need to remember. The effect of Craggs and Lambert, if not clearly and firmly corrected by the Court of Appeal ${ }^{168}$ or the Supreme Court, would be to allow the market-liberal extremists of the early twentieth century to win by posterity's sheer inattention what they lost in Parliament. The immediate message for the court is clear: it must get out its pitchfork and banish Frankenstein again.

For academic lawyers, and some practitioners and judges, there are a number of lessons. First and most obviously, we should pay more attention to the (real) history of the LPA 1925 because it is essential to understanding the provisions of this Act and essential to understanding English land law in general. More broadly, as a case-study, the history of the LPA 1925 suggests that academic lawyers interested in any sort of legislation should pay attention to research in political history, indeed arguably should work with political historians. Such academic lawyers, and practising lawyers and judges in relevant disputes, might further realise that in some circumstances they should consult other types of historical research, or indeed work

\footnotetext{
$\overline{168}$ As indicated above, it is strongly arguable that the Court of Appeal judgments in both Lambert and Craggs were per incuriam.
} 
with other types of historians, notably when considering 'updating' interpretation: ${ }^{169}$ people's beliefs about the past (and about the present) often turn out to be wrong as a matter of fact. $^{170}$

Still more broadly, proper history of the LPA 1925 considered together with the historiography and judgments raises important questions about the routes and processes by which academic work can influence judges. We tend to think of academic influence on judges in simple terms, judges reading academic work or having personal contact with academics. ${ }^{171}$ But, over time, the influence of academic attitudes and preconceptions via legal education may be much greater - not only directly, in the effect on judges of their own legal education, but indirectly, in the effect on practitioners. Practitioners largely determine what cases come before the court and how they are presented and argued; and, as practitioners are generally younger than judges, this is a route by which more recent academic ways of seeing, and of not seeing, will affect judges.

There is a good deal of research considering the influence of legal scholarship on practice and the courts for a range of periods down to the early twentieth century,

${ }^{169}$ See J. Bell and G. Engle (eds), Cross: Statutory Interpretation, 3rd ed. (Oxford 1995), 51-52, and F.A.R. Bennion and O. Jones, Bennion on Statutory Interpretation, 6th ed. (London 2013), 797 (section 288).

${ }^{170}$ Modern interest in the doctrine that "statute is always speaking" was triggered by $R v$ Ireland [1998] AC 147, in which the House of Lords resorted to 'updating' on the basis of sheer assertion about the past; had they considered historical work and evidence, 'updating' would not have been necessary.

171 A useful short survey is contained in J. Beatson, "Legal Academics: Forgotten Players or Interlopers?", in A. Burrows et al (eds), Judge and Jurist: Essays in Memory of Lord Rodger of Earlsferry (Oxford 2013), 523-542. 
including, most helpfully, detailed studies regarding specific areas of law; ${ }^{172}$ but there is little for the past half-century. In this period, first, the expansion of higher education plus changes in professional-qualification rules meant that many more practitioners were exposed to academic legal education; second, the culture of English academic law changed significantly, moving away from a focus on practice and the court and devaluing what came to be called "doctrinal" work-core legal research, seeking to understand what the existing law is. ${ }^{173}$ The combination of these two factors is likely to have affected the nature and quality of academic influence on judges; and the effect over time, at least in some areas of law, is likely to have been harmful to real people and to the development of the law. ${ }^{174}$

Finally, and relatedly, there is a lesson for all academic lawyers wishing to make social-policy or political arguments. As a case-study, proper history of the LPA 1925 considered together with the historiography and judgments shows what happens when academic lawyers intent on making social-policy or political arguments disdain proper attention to history and to the law: academics explicitly opposed to market liberalism have ended up fostering it. For the avoidance of doubt: although it is clear from this article that the author does not support market liberalism, the purpose of the

172 e.g. W. Swain, The Law of Contract 1670-1870 (Cambridge 2015), P. Mitchell, A History of Tort Law 1900-1950 (Cambridge 2015); the latter is remarkable for such a late end-date.

${ }^{173}$ See e.g. R. Abel, The Legal Profession in England and Wales (Oxford 1988), 48, 144; W. Twining, Blackstone's Tower: The English Law School (London 1994); F. Cownie and A. Bradney, “An Examined Life: Research into University Legal Education in the United Kingdom and the Journal of Law and Society" (2017) 44 J Law and Soc S129; M. Dixon, "A Doctrinal Approach to Property Law Scholarship: Who Cares and Why?", in S. Bright and S. Blandy (eds), Researching Property Law (London 2016), 1-10. 
article is clearly not to try to persuade readers to share this view. If this had been the or even a purpose, the article would have presented reasons why they should, including of course evidence of current social and economic circumstances.

Instead, the article builds the necessary foundation for any at all sensiblerooted in reality, productive rather than counterproductive- social-policy or political arguments, from whatever perspective, regarding this area of law and suggests the sort of foundation needed for such arguments in any area of law. The fact that such foundations are unlikely to support market liberalism is merely a consequence of the nature of English common law, properly understood. ${ }^{175}$

${ }^{174}$ As feared by at least two eminent academic judges: see Beatson, pp 537-542, and H. McQueen, “Alan Ferguson Rodger (Lord Rodger of Earlsferry) 1944-2011” [2016] Jur Rev 255, 286.

175 Cf. T.R.S. Allan, "Principle, Practice, and Precedent: Vindicating Justice, According To Law" (2018) 77 C.L.J. 269. 